\title{
Örgütsel İletişim: Eğitim Kurumlarındaki Yeri ve Önemi Açısından Bir Değerlendirme
}

\author{
DOI: $10.26466 /$ opus. 350484 \\ Mustafa Güçı̈̈
}

*Doç. Dr., Erciyes Üniversitesi, Eğitim Fakültesi, Kayseri/Türkiye

E-Posta: mguclu@erciyes.edu.trＯRCID: $\underline{0000-0002-7565-3554}$

Öz

Günümüzde iletişim hayatın her alanında olduğu gibi eğitim örgütlerinde de önemli bir yere sahip. Bu araştırmanın amacı örgütsel iletişim konusunu eğitim kurul yeri ve önemi hakkında bilgi vermek, konuya ilişkin araştırma sonuçlarından hareketle günümüz eğitim uygulamalarına ışık tutmaktır. Bu amaç çerçevesinde kütüphane ve internet ortamında "iletişim", "örgütsel iletişim" anahtar kavramlarıla taramalar yapılmıştır. Bu tarama sonucu amaca uygun bulunan makale, tez ve kitaplar incelenmiştir. Betimsel analizin kullanıldığı araştırma sonunda; örgütsel iletişimin örgütün amaçlarının gerçekleştirilmesinde, kurum içinde karar aşamasında gerekli olan bilgilerin toplanması ve alınan kararların etkili bir şekilde uygulanmasında önemli bir etkiye sahip olduğu görülmüştür.

Anahtar Kelimeler: Eğitim, eğitim örgütleri, iletişim, örgütsel iletişim 


\title{
Organizational Communication: An Assessment in Terms of Place and Priority in Educational Instituti- ons
}

DOI: $10.26466 /$ opus.350484

\begin{abstract}
Nowadays communication has an important place in education organizations as well as in every field of life. The objective of this research is to give information about the place and importance of the educational institution in organizational communication and to shed light on today's education practices from the results of the research related to the subject. Within the scope of this aim, "communication" and "organizational communication" were scanned in the library and internet environment. The articles, theses, and books that were found to be suitable for this screening purpose were examined. At the end of the research using descriptive analysis; it has been seen that in the realization of organizational communication, organizational communication has an important effect in gathering the information required in the decision phase within the organization and in the effective implementation of the decisions taken.
\end{abstract}

Key Words : Education, educational organizations, communication, organizational communication 


\section{Giriş}

Eğitim örgütleri toplumsal değişim konusunda itici kuvvetlerden birisidir (Durmuşçelebi, 2015; 2017; Karagöz ve Duman, 2014; Toprak ve Yakar, 2017). Diğer örgütlerde olduğu gibi eğitim örgütleri de, belli amaçları gerçekleştirmek için belirli insan topluluğunun bir araya gelmesiyle oluşur ve bu amaçlara yönelik olarak çalışırlar. Eğitim örgütleri daha önceden belirlenen bu amaçları gerçekleştirmeleri için etkili bir iletişim ağını oluşturmaları gerekmektedir. Öğrencilerde iletişim engellerinin ortadan kaldırılması ve öğrencilerin iletişim becerilerinin geliştirilmesi eğitim programlarının önemli hedeflerindendir (Çetinkaya ve Toprak, 2016). Bir örgütün yaşayabilmesi, kurumun amaçları doğrultusunda etkili bir iletişim politikasının oluşturulabilmesine bağlı görülmektedir. İletişim, örgütsel sürecinin oluşması için gerekli olan kişiler arası bir ilişkilerde önemli bir yere sahiptir. Buradan hareketle iletişimin, insanların sosyal bir grup olarak uyumlu bir şekilde çalışmaların sağlayan bir bağ olduğu söylenebilir. Bu bağ, iki insanı birbirine yakınlaştırıcı olduğu kadar uzaklaştırıcı rol da oynayabilir. Grubun etkin bir şekilde çalışması isteniyorsa, bu grubu oluşturan bireyler arasında bilgi, fikir ve duyguların karşılıklı olarak aksatılmadan iletilmesi gerekmektedir (Elma, 2003).

İletişim konusu örgütsel psikolojide önemli bir yere sahiptir (Karagöz, 2016). İletişim, sadece örgütlerde değil aynı zamanda sosyal yaşamın içinde yer alan bütün insanlar için de önemli olan bir konudur. Başka bir deyişle iletişim; anne, baba, çocuk, akraba, arkadaş, öğrenci, işgören-işsiz ve yöneticiler açısından anlam ve önemi fazla olan bir sosyal olgudur. Toplumsal yaşamın temelinde yer alan ve örgütsel yapının özünü oluşturan iletişim düzeni, gruplar ve kurumlar arasında ilişkiler kurmayı amaçlayan bir süreçtir. İnsanların birbirlerini daha iyi anlamaları ve tanımları, bir kurumda işlerin daha iyi yapılabilmesi ve sorunların daha iyi çözülmesi için sağlıklı bir iletişime ihtiyacı vardır (Güney, 2012).

İletişim ve kendini doğru ifade etme, insanların meslek hayatlarında başarılı olmalarının en önemli etkenlerinden birisidir. Bir kimsenin herhangi bir konuda doğru ve sağlıklı karar verebilmesi için ne gibi olanaklara sahip olduğunu bilmesi gerekir (Bozgeyikli, Toprak ve Derin, 2016). Eğitim kurumlarında da yöneticilerin ve öğretmenlerin birbirleriyle etkili iletişim kurmaları, hem kendilerinin başarılı birer birey olarak örgütte yer 
almalarına hem de başkalarını bilgilendirerek ifade etmek istedikleri konunun tam ve anlamlı olarak öğrenilmesine faydaları olur (Durmaz, 2004). Buradan hareketle eğitim örgütlerinin istenen verimi sağlayabilmesi, amaca uygun hareket edebilmesi için örgütsel iletişimin son derece önemli olduğu görülmektedir.

$\mathrm{Bu}$ araştırmada eğitim örgütlerinde örgütsel iletişimin yeri ve önemi hakkında bilgiler verilmiştir. Bunun için öncelikle iletişim ve örgütsel iletişim kavramları tanımlanmış, özelliklerine değinilmiştir. Daha sonra ise eğitim kurumlarında örgütsel iletişimin yeri ve önemi hakkında bilgiler verilmiştir.

\section{Bir Kavram Olarak İletişim}

İletişime ilişkin literaürde çok sayıda tanım yer almaktadır. Bu tanımlardan birisinde iletişim sözcüğü, Latince kökenli "communication" sözcüğünün karşıllı̆ı olarak ifade edilmektedir. Birbirlerine ortamlarındaki nesneler, olaylar, olgularla ilgili değişmeleri haber veren, bunlara ilişkin bilgilerini birbirine aktaran, aynı olgular, nesneler, sorunlar karşısında benzer yaşam deneyimlerinden kaynaklanan, benzer duygular taşıyı bunları birbirine ifade eden insanların oluşturduğu topluluk ya da toplum yaşamı içinde gerçekleştirilen tutum, yargı, düşünce, duygu bildirişimlerine iletişim denmektedir (Oskay, 2011).

Bursalığlu'na (2005) göre ise iletişim, insan davranışını değiştirmek amacıyla her türlü kavram ve sembolün iletilme sürecidir. İletişim yoluyla kişiler arası ilişkiler düzelir veya bozulur. Böylece örgüt gelişir veya kötüleşir. Örgüt bir iletişim ağı olarak düşünülebilir. Çünkü örgüt daima değişen etken bir varlık olup biyolojik ve fiziksel öğeleri vardır, kişiler arası ilişkiler üzerine kurulur. Örgüt, içinde karar örneklerinin iletilme ve yayılmasını sağlayarak, iletişim karar sürecinin gerçekleşmesinde de yardımcı olur. Görüş ve anlayıştaki katılmayı arttırmak yoluyla iletişim, sistemin parçalarını bir araya getirir ve kaynaştırır. Aynı zamanda yetkinin görevlerini de destekler ve gerçekleştirir. Koordinasyonu sağlayan araçlardan en güvenilir ve en etkili olanı iletişimdir (Bursalıŏlu, 1994). Dökmen'e (1994) göre iletişim kısaca bilgi üretme, aktarma ve anlamlandırma süreci olarak da tanımlamak mümkündür. Bu durumda pek çok etkinlik iletişim sayılacaktır. Örneğin; bu tanıma dayanarak iki insanın karşılıklı 
konuşmasını iletişim sayabileceğimiz gibi, onların bağlı bulunan yeri birbirlerine bildirmelerini de iletişim kabul edebiliriz.

Taymaz'a (2003) göre iletişim, toplumsal birimler arasında bir bilgi, anlam, duygu ve düşünce alışverişidir. Taymaz'in tanımdan hareketle toplumun birimleri arasındaki her türlü alışveriş iletişimle sağlanmaktadır. Yine bu tanımdan hareketle iki birim arasında kurulamayan ya da yanlış işleyen bir iletişim sürecinin bilgi, anlam, duygu ve düşünce alışverişinin akışına engel olacağı söylenebilir.

Gökçe (2006) ise iletişimin tanımında çağrışım kavramına vurgu yapmakta ve iletişimin kişilerin sözlü ya da sözsüz ortak simgeler aracilığıyla bilgi, düşünce, inanç, duygu vb. karşılıklı olarak aktarmaları sonucu, zihinlerinde aynı ya da benzer çağrışımlar söz konusu olduğunda ya da aktarılan iletilerin karşılıklı olarak benzer çağrışımlara yol açması durumunda gerçekleşebildiğini belirtmektedir. Burada da görüldüğü gibi Gökçe'ye göre iletişimde esas olan çağrışımdır.

Bayraktutan (2008) iletişimin bireysel ve sosyal açıdan önemli işlevler yerine getirdiği belirtmektedir. Ona göre iletişim bireysel gereksinimlerin karşılamasında, çıkarları korumada, amaçlara ulaşmada bir araç olarak kullanılabilmektedir. Yine iletişim, kişisel olarak anlık bir gereksinimi ya da daha uzun sürede ulaşılabilecek bir hedefin gerçekleşmesinde de son derece etkilidir. Ayrıca iletişim, değişiklik yaratmak, koşulların değiştirilmesini sağlamak için bir araç olabilmektedir. Bayraktutan'a göre iletişim sürecinde kişi kendi inançlarını, duygularını daha iyi çözümleyebilmektedir.

İletişim bireysel açıdan olduğu kadar sosyal açıdan da önemli işlevler üstlenmektedir. Bayraktutan (2008), Laswel'den yapmış olduğu alıntıda iletişimin sosyal işlevini üç açıdan değerlendirmektedir. Bunlar;

- Çevreyi denetleyerek toplumun da değerlerini denetlemek.

- Toplumun bireyleri arasında etkileşimi sağlamak.

- Toplumsal geleneklerin sürdürülmesine yardımcı olmak.

İletişimin sosyal işlevlerine ilişkin bu bilgilerden hareketle iletişimin; bir toplumsal denetleme mekanizması olması, toplumu oluşturan bireyler arasında etkileşimi sağlaması ve geleneklerin varlığını devam ettirmesi gibi önemli işlevler üstlendiği görülmektedir. Bunların yanında iletişimin; 
toplumu bilgilendirip yönlendirmesi, kültürel aktarımı ve yakınlaşmayı sağlaması gibi önemli sosyal işlevler de görmektedir. Sosyalleşen insanların çevresiyle iletişimi kolaylaşmakta bu da beraberinde güçlü iletişim bağlarını oluşturmaktadır (Toprak ve Bozgeyikli, 2011).

Aynı zamanda sosyal bir varlık olan insanın toplumsal yaşamdan bütünüyle kopuk bir hayat sürmesinin düşünülemeyeceğini belirten Sabuncuoğlu ve Gümüş'e göre (2008) insan var oluşunun farkına, kendi dışındaki başkalarıyla kurduğu iletişim sayesinde varabilmektedir. Bu görüşten hareketle iletişimin öncelikli amacının, sosyalleşme ve toplum içindeki diğer insanlarla etkileşim kurarak kendini gerçekleştirme ihtiyacının karşılanması olduğu söylenebilir.

İletişim farklı türleri vardır. Şekil türleri olarak iletişim; bireyin kendisi ile olan iletişimi, kişilerarası iletişim, toplumsal iletişimi, kitle iletişimi ve örgütsel iletişim olmak üzere beş başlık altında incelenmektedir (Tunç, 2015).

Tanımlardan ve özelliklerinden anlaşıldığı gibi iletişim süreci en az iki kişi arasında gerçekleşmektedir. İletişim süreci öncelikle kaynak kişinden gelen mesajla başlamaktadır. Daha sonra duygu ve düşünceleri ifade etmek için oluşturulan iletinin kodlanması, bu iletiyi en etkili bir şekilde iletecek aracın seçilmesi ve bu yolla hedefe, eş deyişle, alıcıya gönderilmesi, alıcının ise iletiyi aldıktan sonra kod açımını yapması ve iletiyi gönderen kişiye bir karşılık olarak yeni bir ileti oluşturması, kodlaması ve bir araç kullanarak göndermesi ile iletişim süreci döngüsel bir işleyişte devam etmektedir. Bu döngüsellikte, süreç devam ettiği sürece kaynak ve hedef sürekli yer değiştirmekte ve yeni iletiler üretilmektedir (Vural, 2012). Bu döngüsellikten hareketle iletişimin en az iki arasında geçen bir süreç olduğu söylenebilir.

\section{Bir Kavram Olarak Örgütsel İletişim}

Bir kavram olarak örgüt; örgütsel amaçların gerçekleştirilmesi amacıyla oluşturulmuş yapıyı, birlikteliği ifade etmek için kullanılmaktadır. Örgütte meydana gelen olaylar birbirinden farklı, bağımsız değil karşılıklı olarak birbirine bağımlıdır. Örgütsel iletişim ise örgütte çalışan kişi ve grupların, kurumun ortak amaçları doğrultusunda gerçekleştirdikleri ileti alışverişi olarak tanımlanabilmektedir (Tutar, 2003). 
Sosyolojik ve psikolojik farklı yönleri olan örgütün formal ve informal olmak üzere iki tür yapısı vardır. Formal örgüt yapısı, belirli bir amaç istikametinde, önceden planlanmış ve bilinçli olarak oluşturulmuş ilişkiler topluluğu şeklinde ortaya çıar. İşlerin nasıl gruplandığını, kimin kime karşı sorumlu olduğunu, mevkiler ve unvanlarını, personelin örgüt içindeki yerini belirleme olanağı bulunmasına karşılık, işlerin tanımını, örgütte ne tür bir yönetim tarzının uygulandığını, her kademenin sahip olduğu yetkiyi ve fiili haberleşme düzeyini belirleme olanağı bulunmamaktadır. İnformal örgüt ise formal örgüt yapısındaki kademe ve mevkilerin çalışanlarca doldurulması sonucunda oluşan ve herhangi bir ön planlama ve bilinçli bir düzenleme evresi olmayan, ancak bireyler arası ilişkiler sonucu oluşan bir yapı olarak ifade edilebilir (Şimşek, 2002).

Örgüte ilişkin yapılan bu tanımlamalar ve açıklamalar doğrultusunda örgütsel iletişimin kurumun başarısında çok önemli bir yere sahip olduğu görülmektedir. Örgütsel iletişime ilişkin farklı araştırmacılar tarafından yazılmış değişik tanımlar bulunmaktadır. Ortak bir amaç için bir araya gelmiş kişi ve kurumların oluşturduğu örgütte iletişim kavramı genellikle kuruma ait, kurum içi ve kurumun diş çevresiyle yaptığı iletişimi ifade etmek için kullanılan bir kavram olarak dikkat çekmektedir. Bu kavram, örgütün yaptığ1 ve örgütte yapılan iletişim olarak değerlendirilebilir. Örgütün yaptığ 1 diş çevreyle iletişimi ifade ederken örgütte yapılan örgüt içi iletişim anlatılmaktadır. Örgütsel iletişim, "örgüt yönetimlerinin örgüt ile ilgili etkileri iletişim kanallarını kullanarak örgütün iç ve dış çevresine iletmeleri olarak" şeklinde ifade edilmektedir (Gürüz ve Gürel, 2006).

Bir kavram olarak örgüt içi iletişim; çalışanların eğitilmesi, kurumsal değerlerin ve kültürün benimsetilmesi ve çalışanların örgüt amaçları doğrultusunda sosyalleştirilmeleri, örgütün faaliyetlerinin çalışanlara tanıtımı, örgütün politika ve stratejilerinin tüm personele benimsetilmesi ve onların desteğinin sağlanması, kurum içi motivasyonun ve iş doyumunun arttırılmasına yönelik katkılar yoluyla verimliliğin teşvik edilmesi ve örgütün diş çevresine de, örgütle ilgili bilgi alabilecekleri bir temel kaynak işlevi görmesi biçiminde özetlenebilmektedir (Ural, 2001).

Örgütsel iletişimle ilgili yapılan tanımlarda vurgulanan konulardan birisi de toplumsal süreçle ilgili olanıdır. Örgütsel iletişim, işletmelerin işleyişlerini temin etmek ve işletmeyi amaçlarına ulaştırabilmek gayesiyle, gerek örgütü meydana getiren türlü öğeler ve bölümler, gerekse kurum 
ve çevresindekilerle birlikte girişilen sürekli bir bilgi ve düşünce alışverişine yâda bölümler arasında lüzumlu ilişkilerin kurulabilmesine olanak sağlayan toplumsal bir süreç olmaktadır. Görüldüğü üzere, görüldüğü üzere, örgütsel yapının özünü oluşturabilen iletişim sistemleri; gruplar, kişiler ve örgütler arasındaki ilişkileri kurmayı hedefleyen bir olgu olmaktadır (Budak ve Budak, 2004).

Mc Donald'a ve Tanner (1999) ise örgütsel iletişimi resmi bir süreç olarak görmekte ve örgütsel iletişimi, belirli bir amacı gerçekleştirmek üzere planlanmış, koordine edilmiş, resmi bir süreç olarak değerlendirmektedirler.

Örgütsel iletişim tekyönlü bir süreç değildir. Örgütsel iletişim, örgütsel amaçları gerçekleştirmek için yapılan işlem ve eylemlerden geribildirim yoluyla tepkileri, yanıtları da kapsamaktadır. Ĕger geribildirim kanalı kapalı ise bu iletişim süreci sağlıklı değildir. Örgütsel iletişim, hem yöneticinin işgöreni etkilemesini, hem de işgörenin yöneticiye yanıtını içeren çift yönlü bir iletişim süreci olarak gerçekleşir (Kurudayığlu ve Deniz, 2001).

Örgütsel iletişimin amaçları aşağıdaki maddeler şeklinde sıralanabilir (Ekinci, 2006):

$\checkmark$ Yönetici ve çalışanların kuruluşun temel uygulamaları, sorun ve amaçlarının farkına varmalarının sağlanması,

$\checkmark$ Kuruluş ve çalışanları etkileyecek önemli gelişmeler hakkında gerek yöneticiler gerekse çalışanların bilgilendirilmesi,

$\checkmark$ Dayanışmanın sağlanması ve çalışanların cesaretlendirilmesi,

$\checkmark$ Çalışanların yönetime katılmalarının sağlanması, bilgilendirme isteklerinin gerçekleştirilmesi.

Gürsel (2006a ve 2006b) örgütsel iletişim türlerini formal ve informal olarak ikiye ayırmaktadır. Formal iletişim örgütteki, hiyerarşik otorite yapısıyla ilgilidir ve rasyonel, planlanmış bilgi akımının sağladığı kararlardan oluşur. Örgüt şemaları ve yönetmelikleri, kimin kiminle iletişim kuracağını açık olarak belirtir. Formal haberleşme ile örgüt içindeki iletişim kanalları bir düzene sokulur ve bazı sınırlamalar getirilir. Formal haberleşme, yukarıdan aşağıya iletişim, aşağıdan yukarıya iletişim, yatay iletişim ve çapraz iletişim olarak dörde ayrılır. İnformal iletişim kişiler arası 
ilişkiler ağı yoluyla çalışır ve örgütün informal yanını işletir. İnformal iletişim, üyelerin örgüte karşı takındıkları tutumların göstergesidir. Formal iletişim sistemi ne kadar bozuk olursa, informal iletişim ve söylentiler de o derece artar. Bu söylentiler eyleme geçirme, saptırma, eleme, şiddetlendirme gibi özellik ve etkiler taşır. Örgütte asıl görevi kaynaştırma olan iletişim, çözülme görevi yapar. Bunun sonucu olarak, grupların dağılması, ilişkilerin bozulması, moral düşmesi vb. görülmeye başlar.

Tıpkı insanlar arasında var olan iletişim engelleri gibi örgütsel iletişimi de engelleyen bazı etmenler bulunmaktadır. Bu etmenlere ilişkin farklı araştırmacılar tarafından değişik görüşler bulunmaktadır. Bu görüşlerden birisinde Bursalığlu (2005) örgütsel iletişimin önündeki engelleri yedi madde olarak ele almıştır. Bunlar; Psikolojik: Verici ve alıcının görüş çerçeveleri, duygu ve heyecanlar, kişileşmiş kavramlar, saplantılar. 2. Semantik: Konuşma ve yazı dilindeki karışıklık veya inceliklerin neden olduğu farklar ve anlaşmazlıklar. 3. Statü: Verici ve alıcının sosyal ve formal statüleri, akademik ve mesleksel gelişme farları, kaynak sorunu ve ayırımı. 4. Korunma: Vericinin bazı yüklenmeler altına girmesi durumunda önceden hazırlayacağı savunma mekanizmaları. 5. Alan: İletişim merkezleri ile birimleri arasındaki uzaklık. 6. Hiyerarşi: Üst-ast ilişkilerinde çatışmalar, yetkinin oldukça az veya aşırı derecede aktarılması, fazla dar yahut geniş kontrol alanı, düzensiz enformasyon akımı. 7. Uyutma: Karar sürecine katılma olanağı verilmeyen uygulayıcıların, emirleri savsaklaması veya önemsiz sayması. 8. Sınırlama: Örgütün amaçları ve görevleri gereği, bazı kapsamın sınırlanması veya gizli tutulması. Açkalın (1998:) ise örgütsel iletişim engellerini; amacın net bir şekilde ortaya konmaması, iletiler düzenlenirken alıcının iyi tanımlanmaması, orta kademe yöneticilerin mesajları süzdükten sonra iletmeleri, dönüte dayalı değerlendirme boyutunun önemsenmemesi ve bireylerin iletişimci kişilik kazanamamaları şeklinde beş madde ile açıklamaktadır.

\section{Eğitim Kurumlarında Örgütsel İletişimin Yeri ve Önemi}

Toplumsal bir olgu olan eğitim aynı zamanda toplumun geleceğini kontrol etmek amaciyla yapilan toplumsal bir düzenlemedir. Toplumsal bir düzenleme olan eğitimin yönünü toplum belirlemektedir. Onu özgün ve 
farklı kılan ise toplumun beklentileridir. Çünkü eğitim örgütleri toplumun geleceğe ilişkin özlemlerinin ve beklentilerinin bir simgesidir. Öyleyse, toplumun kendi beklentilerine, özlemlerine ve amaçlarına sahip çıkması beklenir. Aksi halde, toplumsal beklentileri gerçekleştirmek için planlanan eğitim, topluma karşı bir girişim gibi algılanmaya başlar ki, böyle bir durumda amaçlarını gerçekleştirmesi beklenemez (Ilgar, 1996).

Eğitim örgütleri, hiçbir toplumun göz ardı edemeyeceği kadar önemli bir kurumlardır. Eğitim örgütlerinin toplumdaki bu kritik durumu nedeni ile onun da topluma, toplumsal kurum ve kuruluşlara karşı duyarlı olması gerekmektedir. Eğitim örgütleri, eğitim konusunda farklı beklentilere sahip gruplarla ilişki kurmak ve bu ilişkilerde çok dikkatli ve duyarlı olmak durumundadır. Eğitim örgütü-çevre ilişkileri ve bu ilişkilerin sonuçları, son yıllarda üzerinde önemle durulan bir konu haline gelmiştir (Gürses, 2006).

Eğitim kurumlarında örgütsel iletişim, Cumhuriyet öncesi dönem eğitimcilerimizden Sati Bey, İsmail Hakkı Baltacıŏglu ve Halil Fikret Kanat tarafından yazılan makaleler içinde öğretmen, öğrenci, okul yöneticisi ve veli açısından ele alınarak değerlendirilmiştir (Karagöz, 2014).

Eğitim kurumlarının kendine özgü bazı özellikleri vardır. Her şeyden önce eğitim örgütlerinin çalışanları mesleki eğitim görmüş, alanlarının uzmanları öğretmenlerden oluşur. Öğretmenler sadece eğitim yöneticisi kadar değil, eğitim sisteminin en üst yöneticisi kadar eğitim görmüş de olabilirler. Daha yüksek bir öğrenim görmüş olmaları olasılığı bile vardır. Bu durum, özellikle bugün için geçerlidir. Bir meslekte uzmanlık, uygulamada özerklik gerektirir. Bu durum eğitim ve öğretmen için de geçerlidir. Eğitimin niteliği ve eğitimle ilgili kurum ve kuruluşlar, öğretmene yasal bir özerklik kazandırır. Bu özerklik, öğretmen - yönetici ilişkilerinde bazı çatışmalar yaratabilir. Yöneticiler, kendilerini alanlarında söz sahibi olarak algılayan, neyi, nasıl öğretmesi gerektiğine kendisinin karar vermesi gerektiğine inanan, örgütlenmiş meslek elemanları ile karşı karşıya bulunduklarını unutmamalıdır. Yönetimle ilgili eylemlerinde bu gerçeğe dikkat etmeleri gerekmektedir (Aydın, 1994).

Diğer örgütlerde olduğu gibi eğitim örgütleri de, bireylerin tek başlarına gerçekleştiremeyecekleri hedefleri, ortaklaşa bir çaba sonucunda başarmak amaciyla oluşturulur. Örgütsel unsurların bir araya getirilip, düzenlenmesinden sonra, belirlenen hedeflere yönlendirilmeleri iletişimle 
olur. İyi bir iletişim, koordine edilmiş sonuçlara ulaşmak için gereklidir. Etkin bir iletişim, tüm yönetim faaliyetleri için önemlidir (Tutar, 2003).

İletişim süreci kaynak, mesaj, araç, gürültü, alıcl, algılama-değerleme ve geribildirimden oluşur. Bu sürecin etkili bir şekilde işlemesi için; kaynak ve alıcının birtakım becerilere sahip olması, kullanılan araçların yeterli olması, iletişimi gerçekleştirenler arasında saygı, güven ve açıklık ilkesinin esas alınması gerekir. Bu şekilde gerçekleştirilen iletişim örgütsel açıdan olumlu sonuçlar verecektir. Bir örgütte yöneticilerle iyi iletişim kurabilen çalışanların \%90'ının işten tatmin oldukları görülmüştür (Bakan ve Büyükbeşe, 2004).

Örgütsel iletişim, yönetimsel faaliyetlerin yürütülmesinde, karar verme ve ihtiyacı için doğru bilgiye duyulan ihtiyaç iletişim sayesinde sağlanır. İletişim iş etkinliğinin arttırılması ve örgütsel kaynakların harekete geçirilmesi için zorunludur. Organizasyonlarda yönetsel ve örgütsel etkinliklerin yerine getirilmesi, örgütsel iletişim sayesinde olur. Örgütlerde farklı bölümlerin görev ve unvanlarının bulunması örgütsel hiyerarşiyi doğurmaktadır. Yapı olarak örgütsel hiyerarşi farklı birimler arasında formal ve informal iletişim kanallarının bulunmasını zorunlu kılmaktadır (Tutar, 2003).

Eğitim kurumları için iletişim oldukça önemlidir. Çünkü örgütlerin var olabilmesi, belirli bir düzen ve yapı içinde etkili bir iletişim sisteminin varlığını gerekli kılmaktadır. Bir sistem olarak iletişimin en önemli işlevini de kısaca, kurumsal ilişkilerin belirli bir düzen içine sokulması ve böylece kurumsal amaçlarla bireyse amaçlar arasında bilinçli bir dengenin kurulmasıdır. Kurum içi iletişim, bir organizasyonu çeşitli birimleri ve çalışanlar arasında bilgi duygu anlayış ve yaklaşım paylaşımını, bu paylaşma sürecinde ki her türlü araç -gereç ve yöntemi, söz konusu aktarma ile ilgili çeşitli iletişim kanalları ve mesaj şeklini içermektedir. Kurum içi iletişim, bireysel, bireyler arası ve gruplar arası iletişim boyutlarının yanı sıra kurumun dış çevre ile olan iletişim boyutunu da kapsar. Bu yapısı ile iletişimi, kurumun bütünlüğünü sağlayan ve sinir sistemi gibi örgütün her yanını saran bir olgu olduğu söylenebilir (Uztuğ, 2009).

Günümüz eğitim kurumlarının en önemli özelliklerinden biri de bilgiden yararlanabilme ve bilgi üretmedir. Bu da iletişimin önemini bir kat daha artırmaktadır. Eğitim kurumlarında iletişim, tüm yönetim fonksi- 
yonlarının temel taşı olarak görülmektedir. İletişim olmazsa, bilgi transferi gerektirdiği için planlama, örgütleme, yöneltme, koordinasyon ve denetleme faaliyetleri imkânsız hale gelmektedir. Bu da örgüt için felaket demektir. İletişim aynı zamanda çalışanları motive etmekte, yöneticilerin etkinliğine de katkı sağlamaktadır. İletişim becerisi yöneticilikte temel becerilerdendir. Daha yüksek iletişim becerisi, daha yüksek yönetim becerisi anlamina gelir (Tutar, 2006).

Kurumsal iletişim yönetimsel beceri yanında örgütsel bütünleşme için de son derece gerekli ve önemlidir. Örgütteki tüm öğelerin örgütsel amaçlar yönünde etkileşimde bulunmasını sağlayarak örgütsel bütünleşmenin gerçekleştirilmesinde son derece önemli bir işleve sahip olan örgütsel iletişimin önemini göstermek için çok sayıda araştırmalar yapılmış, örgütsel iletişim örgütsel bütünleşme ve başarının çok önemli bir belirleyicisi olarak saptanmış, iletişimin örgütsel değişim sürecinde de çok önemli bir rol oynadığı belirlenmiştir. Örgütsel iletişim, bilimsel yönetim, insanların birbirlerine karşı yaklaşımı, insan kaynakları yönetimi, sistem yaklaşımı ve kültürel perspektif gibi çeşitli yaklaşımlara dayanmaktadır. Bu yaklaşımlardan her biri iletişim olgusuna ilişkin farklı kavramları ve tanımları öne çıkarmışlardır (Durğun, 2006).

İletişim, eğitim kurumunu bir arada tutan ve kurum için hayati öneme sahip bir unsurdur. Yönetime karar almada gereksinim duyulan bilgiyi elde etme imkânı sağlar. Yöneticilerin aldığı kararların çalışanlar tarafından algılanması ve uygulamaya dönüştürülmesini olanak sağlar. Çalışanların örgüte bağlılığını artırarak, müşteri hizmetlerinin iyileşmesine fırsat verir. İş tatmini, motivasyon, örgütsel bağlılık gibi çalışanların davranışları üzerinde olumlu etkiler yaratır. Çalışanların paylaşım ve yardımlaşma duygusunu artırır. İş ortamındaki sürtüşme ve baskı ve çatışmaları azaltır. Örgütsel faaliyetlerin istikrar ve dayanışma içinde gerçekleşmesine katkı sağlar. Örgütsel değişimde çalışanlar korkmaz, yönetime karşı güven oluşturur ve değişim sürecini hızlandırır. Daha az hata yapılmasına, defolu üretimin düşmesine ve sonuçta giderlerin azalmasına imkân tanır. Karlılığı ve etkinliği artırır. Stratejik planların etkin bir şekilde uygulanabilmesinde önemli katkılar sağlar (Bakan ve Büyükbeşe, 2004 ).

Bir örgütte yapı ne kadar sağlıklı olursa olsun, planlama ne derece iyi yapılırsa yapılsın, yetersiz bir iletişim örgütün amaçlarının gerçekleşmesini olumsuz biçimde etkileyebilir. Toplumsal, kişisel ve örgütsel pek çok 
sorunun genellikle yanlış ya da yetersiz iletişimden kaynaklandığı düşünülürse, çözümlenmesi güç gibi görülen sorunlar iletişim yolu ile daha sağlıklı çözümlenebilir. Karar verme yönetim açısından ne kadar önemli ise, iletişim de örgüt açısından o kadar önemlidir (Bursalıŏlu, 2005).

Etkin bir kurum içi iletişim sistemi; çevresiyle sürekli ilişki içinde olan çalışanların, kurumu daha iyi tanımasını ve iş sürecinin devamlılığını sağlarken, sorumluluk ve moral kazanma gibi örgütsel tutumlarını da olumlu yönde etkilemektedir. Eğitim yöneticileri ile oluşturulan iletişim süreci içinde çalışanlar işi ne için yaptıklarını, örgütün uzun ve kısa vadeli amaçlarının ne olduğunu, kurumun durumunun ne olduğunu, iş sürecinin nasıl işlediğini öğrenerek, yaptıkları işi gerek kendi mantı̆̆ içinde, gerekse örgütsel sistemin genel bütünlüğü içinde anlayıp, öğrenmek isterler. Bu da etkili bir örgüt içi iletişim sistemi ile mümkün olur (Ural, 2001).

Ortak bir amacı gerçekleştirmek için bir araya gelen bireyler, gruplar, topluluklar ve örgütler için iletişimin önemi çok büyüktür. Örgütteki bireyler ve gruplar arasında olması gereken uygun etkileşimi sağlayan öğe ise örgütsel iletişimdir. Örgütsel iletişim bir örgütün varlığını sürdürmesinde ve tüm örgütsel süreçlerde önemli bir rol oynamaktadır. Örgütsel iletişim olmadan herhangi bir örgütsel eylemin ya da yönetim sürecinin başarılması imkânsızdır. İletişimin yeterli olduğu bir örgütte, örgütün amaçlarının doğru olarak anlaşılmış ve kavranılmış olması, örgüt üyelerinin bu ortak amaçların gerçekleştirilmesi doğrultusunda işbirliği içinde eşgüdümlü olarak davranma eğilimi içinde olmaları beklenilmektedir (Durğun, 2006).

Örgütsel iletişimin en önemli amacı faaliyetleri yönlendirmek, yani bireylerin istenilen yönde davranmasını sağlamaktır. Fakat örgütlerde bir değil, birçok faaliyet söz konusu olduğundan, birey ve grupların tüm etkinliklerinin dikkatlice koordine edilmesi gerekmektedir. İşte örgütsel iletişim sadece etkinliklerin yönetilmesinde değil, bu etkinliklerin işler durumda olmasında önemli rol üstlenmektedir (Akıncı, 1998).

\section{Sonuç}

Yapılan çalışmalar günümüzde sosyal, siyasal, kültürel ve teknolojik gelişmelerin iş hayatını oldukça etkilediğini göstermektedir. Eğitim kurum- 
ları da bu etkiler karşısında mücadele edebilmek için yeni yöntem ve teknikler geliştirmekte, amaçlarını, misyon ve vizyonunu gözden geçirmektedir. Eğitim kurumlarının bu koşullar altında verimliliklerini arttırmaları, amaçların gerçekleşme düzeylerinin üst seviyelere çekilebilmesi için önem vermeleri gereken konuların başında şüphesiz örgütsel iletişim gelmektedir. Eğitim örgütlerinin içinde iyi bir iletişim sistemi kurulamaması sonucunda örgüt üyeleri faaliyetlerini birbirinden bağımsız ve kopuk bir şekilde gerçekleştirmeye çalışmakta, amaçların gerçekleşme düzeyi bundan etkilenmektedir. Bu çerçevede eğitim kurumları yöneticilerinin örgütsel iletişimi geliştirmek ve iyileştirmek adına aynı zamanda iyi bit iletişimin özellikleri de olan kurum içindeki çalışanlara karşı açık ve net olmaları, güven vermeleri, dinleme yeteneklerini geliştirmeleri gerekmektedir.

Eğitim kurumlarının kendisinden beklenen verimi sağlaması için öğretmenlerin ve diğer kurum çalışanlarının kurumu iyi tanıması, yüksek bir sorumluluk duygusu ve moral içinde olması gerekmektedir. Bunun içinde örgütsel iletişim son derece önemlidir. Çünkü diğer kurumlarda olduğu gibi eğitim örgütlerinde de çalışanlar kurumun amaçları, kurumun ne olduğu, kurum içinde iş akışının nasıl olduğunu gibi konularda bilgi sahibi olduklarında örgütün amaçlarının gerçekleşme düzeyi artmakta, bu durum da verimliliği doğrudan etkilemektedir.

Örgütsel iletişim eğitim kurumlarında yöneticilerin karar aşamasında bilgi edinmesinde oldukça önemli yarar sağlamaktadır. Bunun yanında iletişim yöneticilerin almış olduğu bu kararların uygulanmasında da katkı sağlamaktadır.

Tüm bu yararlar örgütsel iletişimin eğitim kurumlarında önemini göstermektedir. Bu nedenle eğitim yöneticilerine önemli görevler düşmektedir. Yöneticilerin bu alandaki eksiklikleri için hizmet içi eğitim etkinliklerinin düzenlenmesi, farklı seminerlere katılmalarının sağlanması gibi bazı çözüm yolları geliştirilebilir. Yine lisans eğitimleri sırasında öğretmen adaylarının örgütsel iletişimle ilgili dersler almaları bu alandaki verimin sağlanmasında etkili olabilir. 


\section{KAYNAKÇA}

Açıkalın, Aytaç (1998). Okul yöneticiliği. Ankara. Pegem Yayıncılık.

Akınc1, Z. B. (1998). Kurum kültürü ve örgütsel iletişim. Ankara: İletişim Yayinlar1.

Aydın, M. (1994). Eğitim yönetimi. 4. Baskı, Ankara: Hatipoğlu Yayınevi.

Bakan, İ. ve Büyükbeşe, T. (2004). Örgütsel iletişim ile iş tatmini unsurları arasındaki ilişkiler: akademik örgütler için bir alan araştırması, Akdeniz Üniversitesi İktisadi ve İdari Bilimler Fakültesi Dergisi, Sayı: 7, ss. 4-12.

Bayraktutan, Ş. (2008). İlköğretim okullarında sımıf içi iletişimin öğrenci okul başarısına etkisi (İstanbul ili Kartal ilçesi örneği), Yayınlanmamış Yüksek Lisans Tezi, Beykent Üniversitesi Sosyal Bilimler Enstitüsü, İstanbul.

Bozgeyikli, H., Toprak, E. ve Derin, S. (2016). Öğretmen adaylarının mesleki değer algılarının sıralama yargılarıyla ölçeklenmesi. Hak-İş Uluslararası Emrek ve Toplum Dergisi, 5(11), 204-225.

Budak, G. ve Budak, G. (2004). İşletme yönetimi. İzmir: Barış Yayınları.

Bursalığlu, Z. (2005). Okul yönetiminde yeni yapı ve davranış. Ankara: Pegem Yayınları.

Çetinkaya, Yıldız, E. ve Toprak, E. (2016). Psikolojik danışman adaylarının empatik eğilim, utangaçlık, olumsuz değerlendirilme korkusu ve sosyal beceri düzeylerinin farklı değişkenler açısından incelenmesi. Akdeniz Insani Bilimler Dergisi, VI(2), 513-530.

Dökmen, Ü.(1994). İletişim çatışmaları ve empati, İstanbul: Sistem Yayınc1lik.

Durğun, S. (2006).Örgüt kültürü ve örgütsel iletişim. Yüzüncü Yıl Üniversitesi Eğitim Fakültesi Dergisi, Sayı 3(2), 112- 132.

Durmaz, M. (2004). Kişiler arası iletişim ve motivasyon, İzmir: Ege Üniversitesi Basım Evi.

Durmuşçelebi M. (2015). Öğretmenlik eğitimi programının etkililiği. Pegem Ĕ̆itim ve Öğretim Dergisi, 5, 747-766.

Durmuşçelebi M. (2017). Dünden bugüne öğretim üyelerinin öğretmenlik davranışlarının değerlendirilmesi, Turkish Studies - International Periodical for the Languages, Literature and History of Turkish or Turkic, 12, 155-178. 
Ekinci, Kadir (2006). Örgütsel iletişim ve örgütsel bağhllık arasındaki ilişki, Yayınlanmamış Yüksek Lisans Tezi, Atatürk Üniversitesi Sosyal Bilimler Enstitüsü, Erzurum.

Gökçe, O. (2006). İletişim bilimine giriş. Ankara: Siyasal Kitabevi.

Güney, S. (2012). Örgütsel davranış. 2. Basım. İstanbul: Nobel Yayıncllık.

Gürsel, M. (2006a). Eğitimde yönetim ve sisteme ilişkin çeşitlemeler. Konya: Eğitim Kitabevi.

Gürsel, M. (2006b). Okul yönetimi (6. Bask1). Konya: Eğitim Kitabevi.

Gürses, Y. (2006). Eğitim örgütlerinde yöneticilerin etkili iletişim kurma becerilerinin belirlenmesine yönelik bir araştırma (Kütahya merkez ilçe örneği). Yayınlanmamış Yüksek Lisans Tezi, Dumlupınar Üniversitesi Sosyal Bilimler Enstitüsü, Kütahya.

Gürüz, D. ve Gürel, E. (2006). Yönetim ve organizasyon. Ankara: Nobel Yayin.

Ilgar, L. (1996). Eğitim yönetimi, okul yönetimi, sını yönetimi, İstanbul: Beta Yayınevi.

Karagöz, S. (2016). Cumhuriyet öncesi dönem Türkiye'ye psikolojik testlerin girişi üzerine bir inceleme. OPUS-Uluslararası Toplum Araştırmaları Dergisi, 6(10), 271-285.

Karagöz, S. ve Duman, T. (2014). 1908-1928 yılları arası süreli yayınlarda yer alan eğitim görüşleri ve öneriler. Uluslararası Sosyal Araştırmalar Dergisi, 7(35), 576-594.

Karagöz, S. (2014). Çağdaş Pedagojik Anlayışa Uygun Üç Düşünür ve Üç Yazı (1910-1919):( Sâtı Bey, İsmail Hakkı (Baltacıŏlu), Halil Fikret (Kanat)), OPUS - Türkiye Sosyal Politika ve Çalışma Hayatı Araştırmalarn Dergisi, 4(7) ss.83-99.

Kurudayığlu, M. ve Deniz, K. (2001). İletişim. Ankara: Gazi Üniversitesi. Mc Donald, J. ve Taner, S. (1999). Başarılı iletişim. (Çeviren: Emel Köymen).İstanbul: Dünya Yayıncilık.

Oskay, Ü. (2011). İletişimin A B C'si, İstanbul: Der Yayınları.

Sabuncuoğlu, Z. ve Gümüş, M. (2008). Örgütlerde iletişim. İstanbul: Arıkan Yayıncilik.

Şişman, M. (2002). Öğretim liderliği. Ankara: Pegem Yayıncılık. Taymaz, H. (2003). Okul yönetimi, Ankara: Pegem Yayınları. 
Toprak E., Bozgeyikli, H. (2011). Öğretmen adaylarının sosyal sermaye düzeylerinin karşılaştırmalı incelenmesi (Erciyes üniversitesi örneği), Erciyes Üniversitesi Sosyal Bilimler Enstitüsü Dergisi, 31(2), 125-147.

Toprak E., Yakar L. (2017). SBS 2011 Türkçe alt testindeki maddelerin değişen madde fonksiyonu açısından farklı yöntemlerle incelenmesi, International Journal Of Eurasia Social Sciences, 8(26), 220-231.

Tunç, R. (2015). Okul yöneticilerinin iletişim yeterliliklerinin öğretmenlerin stres düzeyleri üzerindeki etkilerinin incelenmesi (Trabzon Örneği), Yayınlanmamış Yüksek Lisans Tezi, Avrasya Üniversitesi Sosyal Bilimler Enstitüsü, Trabzon.

Tutar, H. (2003). Genel iletişim kavramlar ve modeller. Ankara: Nobel Yayın Dağıtım.

Tutar, H. (2003). Örgütsel iletişim. Ankara: Seçkin Yayıncllık.

Tutar, H. (2006). Sanal ofislerde koordinasyon ve iletişim: Teorik bir çerçeve, Gazi Üniversitesi, Ticaret ve Turizm Eğitim Fakültesi Dergisi, 2, 20-28.

Ural, E. G. (2001). Kurum içi iletişim sürecinde etkin iletişim aracı olarak intranet. Maltepe Üniversitesi Illetişim Fakültesi Dergisi, 1, 105-113.

Uztuğ, F. (2009). Halkla ilişkiler ve iletişim. Eskişehir: Web-Ofset Tesisleri. Vural, İ. K. (2012). Medya ve iletişim. Ed: Halil İbrahim Gürcan, Eskişehir: Anadolu Üniversitesi Yayınları.

\section{Kaynakça Bilgisi / Citation Information}

Güçlü, M. (2017). Örgütsel iletişim: Eğitim kurumlarındaki yeri ve önemi açısından bir değerlendirme. OPUS - Uluslararası Toplum Araştırmaları Dergisi, 7(13), 854-870. 